\title{
RHIZOSPHERE COMPETENT MESORHIZOBIUM LOTI MP6 INDUCES ROOT HAIR CURLING, INHIBITS SCLEROTINIA SCLEROTIORUM AND ENHANCES GROWTH OF INDIAN MUSTARD (BRASSICA CAMPESTRIS)
}

\author{
Shikha Chandra; Kamlesh Choure; Ramesh C. Dubey; Dinesh K. Maheshwari* \\ Department of Botany and Microbiology, Gurukul Kangri University, Haridwar-249404, India \\ Submitted: December 03, 2005; Returned to authors for corrections: September 21, 2006; Approved: January 18, 2007
}

\begin{abstract}
The bacterial strain Mesorhizobium loti MP6, isolated from root nodules of Mimosa pudica induced growth and yield of Brassica campestris. The isolate MP6 secreted hydroxamate type siderophore in Chrom-Azurol Siderophore (CAS) agar medium. Production of hydrocyanic acid (HCN), indole acetic acid (IAA) and phosphate solubilizing ability was also recorded under normal growth conditions. Root hair curling was observed through simple glass-slide technique. In vitro study showed a significant increase in population of M. loti MP6 in rhizosphere due to root exudates of $B$. campestris. In dual culture technique the strain showed a strong antagonistic effect against Sclerotinia sclerotiorum, a white rot pathogen of Brassica campestris. The growth of S. sclerotiorum was inhibited by $75 \%$ after prolonged incubation. Efficient root colonization of mustard seedlings was confirmed by using a streptomycin-resistant marker $M$. loti MP6 $6^{\text {strept }}$. The M. loti MP6 coated seeds proved enhanced seed germination, early vegetative growth and grain yield as compared to control. Also, a drastic decline (99\%) in the incidence of white rot was observed due to application of M. loti MP6.
\end{abstract}

Key-words: Biocontrol, Plant growth promoting rhizobacteria, Seed bacterization, white rot, Mesorhizobium loti, Brassica campestris

\section{INTRODUCTION}

Rhizobia form root nodules by infecting a wide range of legumes (35) and limited number of non-legumes in mutual interaction (36). Attraction and attachment of rhizobia to the tips of root hairs resulting in curling or deformation are the first step of infection leading to symbiosis. Recently, rhizobia have been reported as plant growth-promoting rhizobacteria (PGPR) both with legumes and non-legumes. PGPR, directly and indirectly, promote plant growth by production of phytohormones, biocontrol of phytopathogens and/or improvement of nutritional status of plant (14).

Curling of root hairs induced by rhizobia in non-leguminous plants is a rare phenomenon. Usually curling occurs only when infection is caused by compatible rhizobia, which are correlated with initial steps of root nodule formation (30). Scanning of literature indicates that symbiotic root nodule bacteria multiply and survive in the rhizosphere of non-legumes also under field conditions (19) colonizing their rhizosphere $(2,5)$. Effect of phytoharmones on root hairs of non-legumes becomes unavoidable. Trinick and Habdobas (34) documented the inability of rhizobial strains to colonize roots of some plants, such as Brassicaceae and clover, due releasing of toxic compounds (glucosinolates, isothiocynates, etc.) present in root exudates. Besides, direct growth promotion of different non-legumes by rhizobia has earlier been reported (19). Chabot et al. (8) reported the significant increase in dry matter yield of shoot and total phosphorus content by using a phosphate solubilizing strain of $R$. leguminosarum bv. phaseoli in field trials with maize and lettuce. Such enhancement of yield cannot be ruled out due to the production of indole acetic acid (IAA) and/or biocontrol of plant pathogens (11) involving the rhizobacteria-mediated characteristics of antibiotics, hydrocyanic acid $(\mathrm{HCN})$ and siderophores production.

*Corresponding Author. Mailing address: Departament of Botany and Microbiology, Gurukul Kangri University, Haridwar 249404 ((Uttaranchal) India. Tel.: (91) 1334-246767. E-mail: maheshwari@indiatimes.com 
The present study was aimed at to investigate the effect of plant growth promoting strain of Mesorhizobium loti MP6 on root hair curling, enhancement of plant growth and yield of Indian mustard (Brassica campestris) and its role as a potential biocontrol agent against a fungal pathogen, Sclerotinia sclerotiorium.

\section{MATERIALS AND METHODS}

\section{Bacterial strain}

Bacterial strain MP6 was isolated from root nodule of Mimosa pudica was characterized morphologically, biochemically and physiologically according to Holt et al. (20) and identified as Mesorhizobium loti (9). M. loti MP6 was found most promising based on its antagonistic activity against Sclerotinia sclerotiorum, secondary metabolites production viz., siderophore, indole acetic acid (IAA), hydrocyanic acid (HCN) and phosphate solubilization and intrinsic antibiotic resistance towards certain antibiotics (9). The isolate was maintained on yeast extract mannitol agar (YEMA) (36) at $4^{\circ} \mathrm{C}$ and deposited in the Departmental Culture Collection, Department of Botany and Microbiology, Gurukul Kangri University, Haridwar (India).

\section{Siderophore assay}

Siderophore production by the strain MP6 was estimated qualitatively on a universal medium Chrom-Azurol Siderophore (CAS) agar medium (30). Isolate MP6 was spotted on CAS agar medium and plates were incubated $28 \pm 1^{\circ} \mathrm{C}$ for $48 \mathrm{~h}$. Type of siderophore was detected following the method of Neilands (27). The bacterial culture was grown in YEM broth for $48 \mathrm{~h}$ and contents were centrifuged at $7,100 \mathrm{~g}$ for $15 \mathrm{~min}$ at $4^{\circ} \mathrm{C}$. One $\mathrm{ml}$ of culture supernatant was added to $1 \mathrm{ml}$ of $1 \mathrm{mM} \mathrm{FeCl}_{3}$ and siderophore activity was determined by the method of Gibson and Magrath (13).

\section{Indole acetic acid (IAA) production}

Exponentially grown culture of bacterial strain of MP6 was inoculated in $5 \mathrm{ml}$ YEM broth and incubated at $28 \pm 1^{\circ} \mathrm{C}$ for $48 \mathrm{~h}$. The broth was taken to centrifugation at 7,100 $\mathrm{g}$ for $15 \mathrm{~min}$ at $4^{\circ} \mathrm{C}$. The supernatant was collected and passed through $0.2 \mu \mathrm{m}$ Millipore filter membrane. One $\mathrm{ml}$ of $O$-phosphoric acid was added to $2 \mathrm{ml}$ of bacterial supernatant and allowed to stand for $1 \mathrm{~h}$ to develop the colour. For quantitative measurement of IAA, one $\mathrm{ml}$ of cell-free culture filtrate $(\mathrm{CF})$ was mixed vigorously with $4 \mathrm{ml}$ of Salkowsky's reagent and kept at room temperature for $20 \mathrm{~min}$. Optical density was measured spectrophotometrically at $535 \mathrm{~nm}$. The concentration of IAA in each sample was determined from the standard curve of IAA.

\section{Hydrocyanic acid (HCN) production}

Production of HCN was determined by modified method of Miller and Higgins (26). Bacterial culture (48 h) was streaked on
YEMA amended with glycine $\left(4.4 \mathrm{gl}^{-1}\right)$ with simultaneous addition of a filter paper soaked in $0.5 \%(\mathrm{w} / \mathrm{v})$ picric acid in $1 \% \mathrm{Na}_{2} \mathrm{CO}_{3}$ placed in the upper lid of the Petri plate. After incubation at $28 \pm 1^{\circ} \mathrm{C}$, changes in color were examined. On the other hand, plates devoid of inoculum served as control.

\section{Phosphate Solubilization}

Pikovaskya (PKV) agar plates (28) were spot inoculated with a loopful of culture of isolate MP6. After incubation at $28 \pm 1^{\circ} \mathrm{C}$ for 5 days, formation of a clear zone around the spot was recorded. Quantitative estimation of phosphate solubilization was carried out according to Gupta et al. (17).

\section{Plant Responses to M. loti MP6 in vitro Utilization of root exudates}

Seeds of Brassica campestris were washed with the sterile distilled water followed by surface sterilized with $0.1 \%$ mercuric chloride $\left(\mathrm{HgCl}_{2}\right)$ for 2-3 minutes and washed for at least 6 times with sterile distilled water so as to remove the traces of $\mathrm{HgCl}_{2}$. Sterility was checked by putting seeds on nutrient agar medium (NAM). Surface sterilized seeds of similar shape and size were inoculated on moistened filter paper in sterile Petri plates and incubated at $24 \pm 1^{\circ} \mathrm{C}$ for $72 \mathrm{~h}$ (36). Radicles of B. campestris seeds were aseptically placed in culture tubes containing Knop's solution and incubated at $25 \pm 1^{\circ} \mathrm{C}$ for 5 days (tubes were covered with black mesh) to obtain root exudates. Root exudates of contamination-free tube were pooled and mixed in $35 \mathrm{ml} \mathrm{YEM}$ broth at $15 \%(\mathrm{v} / \mathrm{v})$ and inoculated with $0.1 \mathrm{ml}$ of exponential phase culture of $M$. loti MP6, incubated at $28 \pm 1^{\circ} \mathrm{C}$ on gyrotory shaker at $150 \mathrm{rpm}$ for $48 \mathrm{~h}$. Aliquots of serially diluted culture were plated onto YEMA and colonies were enumerated after 48 h incubation at $28 \pm 1^{\circ} \mathrm{C}(15)$.

\section{Assay of bacterial attachment of plant roots}

A drop of $0.2 \mathrm{ml}$ of $0.3-0.4 \%$ agar $(\mathrm{w} / \mathrm{v})$ was placed on a sterile glass slide $(70 \mathrm{~mm} \times 20 \mathrm{~mm})$. Surface sterilized seeds of $B$. campestris with emerging roots $(5 \mathrm{~mm})$ were placed onto it and inoculated with $0.1 \mathrm{ml}$ of exponential phase culture. Thereafter, it was covered aseptically with cover slip and transferred to culture tubes $(150 \mathrm{~mm} \times 25 \mathrm{~mm})$ containing $25 \mathrm{ml}$ of $\mathrm{N}$-free medium. After incubation at $25^{\circ} \mathrm{C}$ for 6 days, it was observed microscopically (12).

\section{Isolation of Sclerotinia sclerotiorum}

The fungal pathogen, Sclerotinia sclerotiorum causing white rot in B. campestris was isolated from infected roots of $B$. campetris following blotter technique (10). Sections of diseased root (tissues) are incubated on moist filter paper at $20^{\circ} \mathrm{C}$. After several days hyphae transferred to potato dextrose agar (PDA) and incubated at room temperature. The pathogen was identified in the laboratory by observation of the ascoma which is apothecioid in shape and yellow-brown to tan in color. Sclerotia 
formed by this fungus are large, irregular in shape, and darkbrown to black in color. This fungus can be partially identified on plant material by the production of a white fluffy mycelium. The pathogen was maintained on PDA at $4^{\circ} \mathrm{C}$ for further studies.

\section{Antagonism in vitro}

Antagonistic properties of $M$. loti MP6 against $S$. sclerotiorum was tested on YEMA plates using a dual culture technique (32). Five day old mycelial discs (5 mm diameter) were placed in four corners of the modified YEMA (addition of $2 \%$ sucrose) plates. Exponentially grown culture of MP6 was spotted $2 \mathrm{~cm}$ juxtaposed from the fungal disc and incubated at $28 \pm 1^{\circ} \mathrm{C}$ for 5 days. Growth inhibition was calculated by measuring the distance between the edge of bacterial and fungal colonies as compared to control (without bacterium). The zone of inhibition was recorded by formula: Inhibition $(\%)=(\mathrm{C})-(\mathrm{T}) /$ (C) $\times 100$, where, $\mathrm{C}$ is radial growth in dual culture and $\mathrm{T}$ is radial growth in dual culture.

\section{Preparation of $S$. sclerotiorum inoculum}

Inoculum of $S$. sclerotiorum was prepared by growing the pathogen on sterile oat (Avena sativa) grains in vitro. The oat grains containing mycelial fragments plus sclerotia served as inoculum and were added to the sandy loam soil to get $10^{4}$ fungal propagules $\mathrm{g}^{-1}$ before seed sowing.

\section{Seed bacterization and field experiment}

Seeds of B. campestris were bacterized according to Weller and Cook (38). Liquid culture of MP6 was grown on YEM broth at $120 \mathrm{rpm}$ at $28^{\circ} \mathrm{C}$ for $48 \mathrm{~h}$ and centrifuged at $7,100 \mathrm{~g}$ at $4^{\circ} \mathrm{C}$ for 15 min to get the pellet. The culture supernatant was discarded and pellets were washed with sterile distilled water and resuspended in distilled water to obtain a population density of $2.1 \times 10^{8} \mathrm{CFU} \mathrm{ml^{-1 }}$. This suspension was mixed with $1 \%$ carboxymethylcellulose (CMC) to form slurry which was coated on to presterilized seeds of $B$. campestris and dried overnight aseptically for curing. Care was taken to avoid clumping of the seeds. Bacterized and non-bacterized seeds were sown in sandy loam soil $(62.3 \%$ sand, $13.9 \%$ silt, $14.6 \%$ clay, $0.349 \%$ total organic matter, $\mathrm{pH} 6.3$ and $34 \%$ water holding capacity) in four sets of treatments: (i) soil sowed with bacterized seeds, (ii) soil infested with S. sclerotiorum and with sowed MP6-bacterized seeds (iii) soil infested with $S$. sclerotiorum (5 g oat seeds mixed properly), and (iv) soil sowed with non-bacterized seeds (control).

The experiment was conducted using a randomized plot design with three replicates of each treatment. Each plot size was $16 \mathrm{~m}^{2}$ with 12 rows and row to row distance of $30 \mathrm{~cm} .20$ seeds were sown in each row of every plot. For evaluation of disease incidence $(\%)$ following formula was used: Disease incidence $(\%)=\left(\mathrm{T}_{\mathrm{N}}\right) /\left(\mathrm{T}_{\mathrm{E}}\right) \times 100$, where, $\mathrm{T}_{\mathrm{N}}$ is total numbers of diseased seedlings and $\mathrm{T}_{\mathrm{E}}$ is total numbers of emerged seedlings. The plots were irrigated routinely. Seed germination (\%) was noted on the $15^{\text {th }}$ day after sowing (DAS). After 120 days of sowing, plant growth and grain yield were recorded. The data were analyzed statistically by using analysis of variance (ANOVA) to find out significance at $1 \%$ and $5 \%$ level of LSD (least significant difference).

\section{Rhizosphere colonization}

For root colonization, antibiotic marker strain resistance toward streptomycin $\left(100 \mu \mathrm{g} \mathrm{ml}^{-1}\right)$ of $M$. loti ${ }^{\text {Strep+ }}$ MP6 was used. B. campestris plants, bacterized with strains were sampled after $30,60,90$ and 120 DAS and bacterial population on the roots were measured. The endophytic bacterial populations on the roots were analyzed. The roots were cut into $1 \mathrm{~cm}$ long segments and one $\mathrm{g}$ of root segment was dipped in $99 \mathrm{ml}$ of sterile $10 \mathrm{mM}$ potassium phosphate buffer ( $\mathrm{pH} 7.0)$ and vortex 4-5 times to release the rhizosphere bacteria. A dilution of the above suspension was poured into Petri plates containing YEM agar amended with streptomycin $\left(100 \mathrm{mg} \mathrm{ml}^{-1}\right)$ to screen out the population of $M$. $l o t i^{\text {Strep+ }}$. After $24 \mathrm{~h}$ of incubation at $28 \pm 1^{\circ} \mathrm{C}$, cfu $\mathrm{g}^{-1}$ root segment was counted. Population dynamics of $M$. loti $^{\text {Strep+ }}$ was recorded after 30, 60, 90 and 120 DAS. Aerobic bacteria population was measured without amendment of streptomycin into medium.

\section{RESULTS}

\section{Screening for siderophore production}

Culture filtrate of MP6 showed a major peak at $400 \mathrm{~nm}$ which revealed production of a hydroxamate type siderophore. The maximum production of siderophore $\left(32 \mu \mathrm{g} \mathrm{ml}^{-1}\right)$ was recorded after $48 \mathrm{~h}$ of incubation.

\section{Indole acetic acid (IAA) and $\mathrm{HCN}$ production}

IAA production was observed as evidenced by the production of a pink coloured product. Maximum production of IAA $\left(24 \mu \mathrm{g} \mathrm{ml}^{-1}\right)$ was recorded after $48 \mathrm{~h}$ incubation. Strong HCN production was recorded by the bacterial strain $M$. loti MP6 as evidenced by change in colour of filter paper from yellow to reddish-brown after 2-3 days of inoculation.

\section{Phosphate Solubilization}

Formation of clear zone around bacterial colony on Pikovaskya agar medium showed phosphate solubilization by M. loti MP6 strain and maximum activity $(45 \mu \mathrm{g} \mathrm{ml})$ was recorded after $48 \mathrm{~h}$ incubation.

\section{Antagonism in vitro}

M. loti MP6 strongly inhibited the growth of S. sclerotiorum on PDA plates at $28 \pm 1{ }^{\circ} \mathrm{C}$. The growth inhibition $(\sim 75 \%)$ of $S$. sclerotiorum was recorded maximally after 120 days incubation (Fig. 1). 


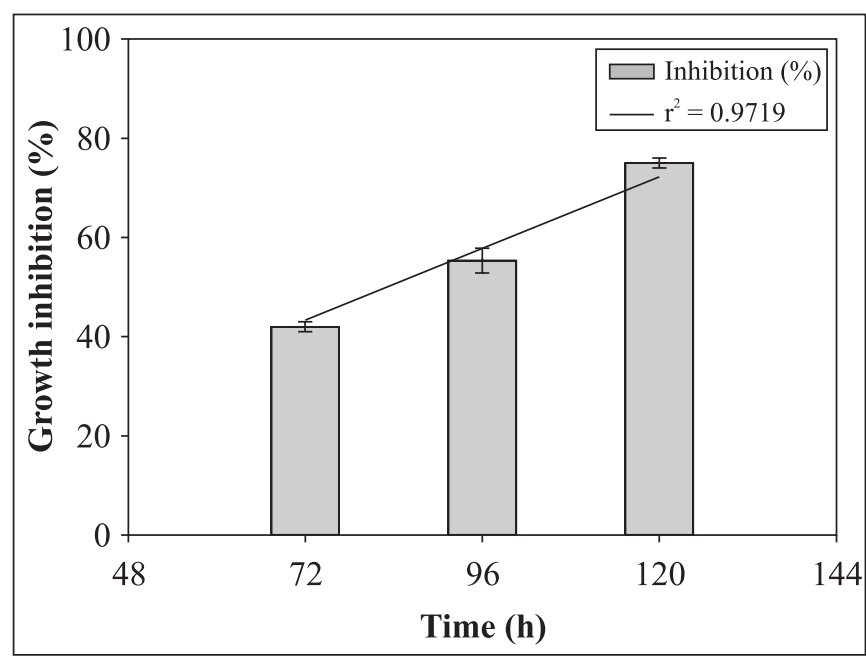

Figure 1. In vitro growth inhibition of Sclerotinia sclerotiorum by M. loti MP6.

\section{Utilization of root exudates and assay of bacterial attachment to roots}

A significant increase in colony forming units (CFU) of $M$. loti MP6 was recorded in the YEMA medium supplemented with root exudates (Table 1). The abundant population in root zone was observed which proved utilization of root exudates by $M$. loti MP6. Bacterial attachment to plant roots demonstrated root hair curling of B. campestris (Fig. 2) and enhanced early plant growth parameters and nitrogen content of plant (Table 2).

\section{Rhizosphere colonization}

The antibiotic marker strain M. loti MP6 ${ }^{\text {Strep+ }}$ showed positive root colonization (Table 3). The bacterial population in the root zone was increased tremendously after 30 DAS, thereafter, it maintained more or less a stationary population (Table 3). Strong

Table 1. Growth of Mesorhizobium loti MP6 in yeast extract mannitol broth containing root exudates of Brassica campestris.

\begin{tabular}{lcc}
\hline \multirow{2}{*}{ Medium } & \multicolumn{2}{c}{$\begin{array}{c}\text { Log colony forming units } \\
\text { after incubation at } 28 \pm 1^{\circ} \mathrm{C}\end{array}$} \\
\cline { 2 - 3 } & $0 \mathrm{~h}$ & $48 \mathrm{~h}$ \\
\hline Yeast extract mannitol broth & $1.4 \pm 0.3$ & $5.4^{\mathrm{a}} \pm 0.5$ \\
Root exudates & $1.4 \pm 0.8$ & $4.8^{\mathrm{a}} \pm 0.7$ \\
Yeast extract mannitol broth & $1.4 \pm 0.4$ & $5.8^{\mathrm{b}} \pm 0.2$ \\
+ Root exudates & & \\
\hline
\end{tabular}

Values in each column are the mean of triplets; \pm , standard deviation. Means followed by letters $(\mathrm{a}, \mathrm{b})$ are significantly different $(\mathrm{P}<0.05)$ according to Fischer-test.

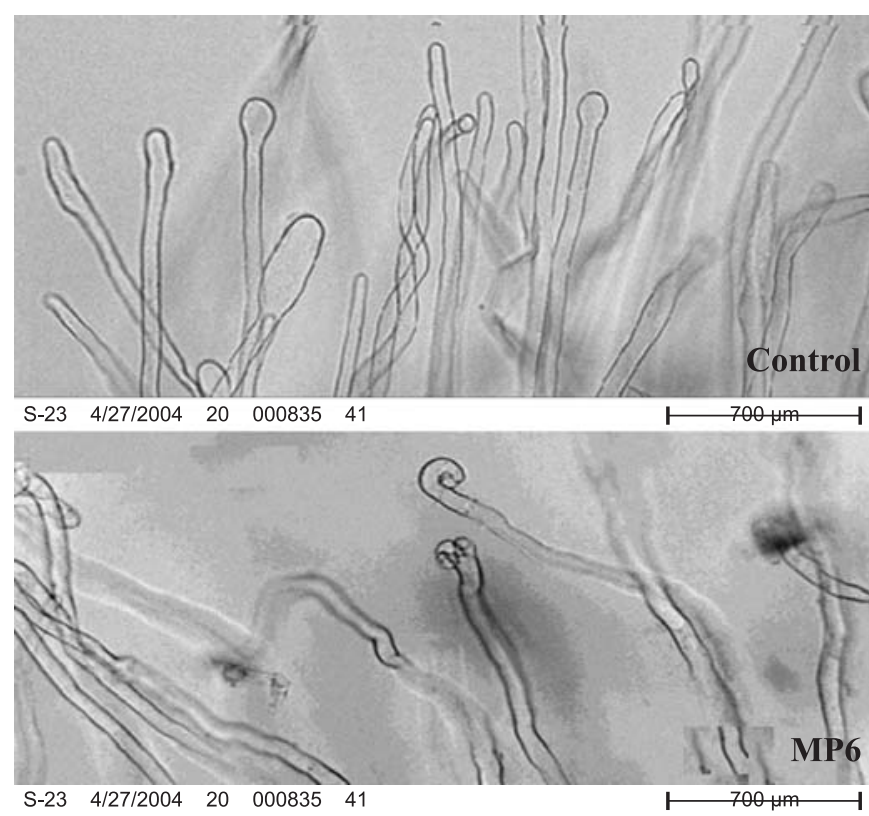

Figure 2. Light photomicrograph of curling of root hairs of Brassica campestris after exposure to Mesorhizobium loti MP6 in comparison to control (un-inoculated), where no such curling in root hairs was observed.

Table 2. Dry weight and nitrogen content of Brassica campestris grown on nitrogen free media with or without Mesorhizobium loti MP6 inoculation.

\begin{tabular}{lccc}
\hline Treatment & $\begin{array}{c}\text { Plant shoot } \\
\text { length } \\
(\mathrm{mm})\end{array}$ & $\begin{array}{c}\text { Plant dry } \\
\text { weight } \\
(\mathrm{mg})\end{array}$ & $\begin{array}{c}\text { Nitrogen } \\
\text { content } \\
(\mathrm{N} \%)\end{array}$ \\
\hline With inoculation & $220^{\mathrm{a}} \pm 0.5$ & $3.2^{\mathrm{a}} \pm 0.15$ & $1.8^{\mathrm{a}} \pm 0.07$ \\
Without inoculation & $70^{\mathrm{b}} \pm 0.7$ & $1.1^{\mathrm{b}} \pm 0.08$ & $0.5^{\mathrm{b}} \pm 0.09$ \\
(Control) & & & \\
\hline
\end{tabular}

Means in each column followed by letters $(a, b)$ are significantly different $(\mathrm{P}<0.05)$ according to Fischer-test.

colonization ability of MP6 lies in it being the successful efficient colonizer both on the mustard seed surface as well as in the rhizosphere.

\section{Field experiment}

Seed bacterization of $B$. campestris with MP6 significantly (5\% level of LSD) induced seed germination (Table 4), early vegetative growth and late reproductive growth as compared to $S$. sclerotiorum-infested soil (Table 5). Seeds bacterized with M. loti MP6 showed $71 \%$ seed germination as compared to $S$. sclerotiorum-infested soil (Table 4). The protection of root 
Table 3. Population of Mesorhizobium loti $\mathrm{MP}^{\text {Strep+ }}$ and general aerobacteria (AB) in rhizosphere of Brassica campestris.

\begin{tabular}{|c|c|c|c|c|c|c|c|c|}
\hline \multirow{2}{*}{ Treatment } & \multicolumn{8}{|c|}{ Population of $M$. loti MP6 in rhizosphere of mustard (CFU/g root segments) } \\
\hline & MP6 & $\mathrm{AB}$ & MP6 & $\mathrm{AB}$ & MP6 & $\mathrm{AB}$ & MP6 & $\mathrm{AB}$ \\
\hline M. loti MP6 & $5.8 \times 10^{4 *}$ & $4.3 \times 10^{3}$ & $6.6 \times 10^{4 *}$ & $4.1 \times 10^{3}$ & $6.5 \times 10^{4^{*}}$ & $3.9 \times 10^{3}$ & $6.5 \times 10^{4^{*}}$ & $3.8 \times 10^{3}$ \\
\hline $\begin{array}{l}\text { M. loti MP6+ } \\
\text { S. sclerotiorum }\end{array}$ & $5.9 \times 10^{4 *}$ & $4.2 \times 10^{3}$ & $3.8 \times 10^{4 *}$ & $3.0 \times 10^{3}$ & $7.0 \times 10^{4 *}$ & $3.8 \times 10^{3}$ & $6.9 \times 10^{4 *}$ & $3.7 \times 10^{3}$ \\
\hline
\end{tabular}

Values are the mean of 3 replicates randomly selected in each set.; *, Significant at 5\% level of LSD (ANOVA); MP6, Total population of $M$. loti $\mathrm{MP6}^{\text {Strep+}} ; \mathrm{AB}$, Total population of aerobic soil bacteria.

Table 4. Effect of seed bacterization with Mesorhizobium loti MP6 on seed germination (\%) and disease incidence of white rot (\%) of Brassica campestris.

\begin{tabular}{lcc}
\hline Treatment & $\begin{array}{c}\text { Seed Germination } \\
\text { (15 days after sowing) }\end{array}$ & $\begin{array}{c}\text { White rot (\%) } 90 \\
\text { days after sowing }\end{array}$ \\
\hline M. loti MP6 & $72^{*}$ & $1^{*}$ \\
M. loti MP6+ & $70^{*}$ & $1.2^{*}$ \\
S. sclerotiorum & $42^{\mathrm{ns}}$ & $99^{\mathrm{ns}}$ \\
S. sclerotiorum & 54 & 13 \\
Control & 1.49 & \\
Cd at 1\% & 0.33 & \\
\pm SEM &
\end{tabular}

Values are the mean of 3 replicates randomly selected in each set.; *, significant at 5\% level of LSD (ANOVA); CD, Critical difference; SEM, Standard error means.

against $S$. sclerotiorum is an added advantage due to application of rhizosphere competent $M$. loti MP6 and resulting in enhanced yield of mustard (Table 5). In S. sclerotiorum-infested soil, plants showed clear white rot symptoms. A drastic decline (99\%) in the incidence of white rot was found where the soil was inoculated with MP6-S. sclerotiorum followed by MP6 alone
(Table 4). In control, seed germination was $28 \%$ higher than $S$. sclerotiorum-infested soil (Table 4). The bacterized seeds in $S$. sclerotiorum-infested soil showed early germination as compared to control. Grain yield also increased by $52 \%$ in case of bacterization of seeds, which was significant at $5 \%$ level of LSD as compared to control (untreated) (Table 5). M. loti MP6coated seeds resulted in 53\% increased grain yield in $S$. sclerotiorum-infested soil as compared to control (untreated) (Table 5).

\section{DISCUSSION}

Few rhizobia are known to produce certain metabolites such as antibiotics (7, 21), siderophores (3) and $\mathrm{HCN}$ (23) which play a significant role in rhizosphere affecting the growth and activity of the other microbes and plant health as well. Based on results, M. loti MP6 produces hydroxamate type of siderophore. Siderophore-mediated competition in reduction of disease incidence results in the exclusion of pathogen in rhizosphere, due to lack of iron required for sclerotia germination and hyphal growth. Due to IAA producing ability of MP6, it is effective for promoting the plant growth. Earlier, 58\% symbiotic nitrogen fixing rhizobia were reported to produce IAA (2) that has been implicated in plant growth promotion (17). HCN produced by

Table 5. Effect of seed bacterization with M. loti MP6 on growth and grain yield of Brassica campestris.

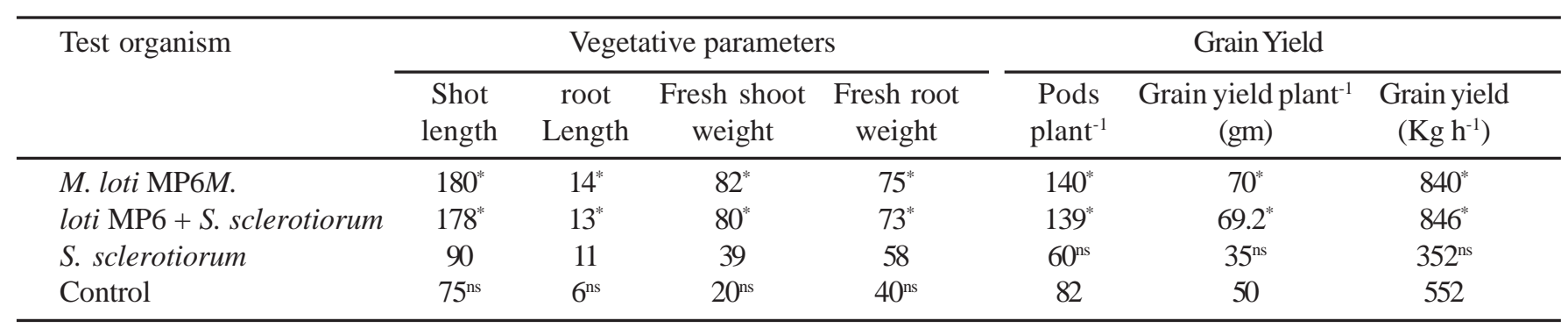

Values are the mean of 3 replicates randomly selected in each set.; *Significant at 5\% level of LSD as compared to control. (ANOVA); ns, nonsignificant at $5 \%$ level of LSD. Length $(\mathrm{cm})$, weight $(\mathrm{mg}), \mathrm{h}$ (hectare) . 
MP6 limited the growth of S. sclerotiorum. Earlier, Bhatia et al. (4) reported that volatile $\mathrm{HCN}$ exhibited inhibition of sclerotia germination of Macrophomina phaseolina. The mode of action of HCN in disease control is partially understood (18). Our results show that MP6 has potential to solubilize inorganic phosphates. Several rhizobia can solubilize inorganic phosphate (3). Many rhizospheric bacteria have ability to solubilize inorganic phosphate from soil. Such bacteria improved solubilization of unavailable soil phosphate accounting high efficiency of phosphorus use. In vitro results of growth inhibition of $S$. sclerotiorum may be attributed to the antagonistic properties shown by MP6. Microscopic examination showed the unfolding, abnormal intercalary swelling, tip deformation, degeneration of cytoplasm and lysis of hypae of fungal pathogen S. sclerotiorum during interaction with rhizobia (11). A similar observation has also been made by Gupta et al. (17) by using fluorescent pseudomonads.

Population of MP6 got increased in the rhizosphere which reflects its potentiality to utilize the root exudates as energy source. Root exudates such as free amino acids, proteins, carbohydrates, alcohols, vitamins or hormones are the important sources of nutrients for the microorganisms present in the rhizosphere and participate in colonization process through chemotaxix of soil microorganisms (25). These features of MP6 facilitate to colonize the rhizosphere. A strong correlation between root exudation and ability to reach high growth rates on exudates have also been demonstrated by Kuiper et al. (24).

As observed in the present study the root hair curling of $B$. campestris, various workers $(31,33)$ have also observed the involvement of rhizobia in root hair curling of rice, oat, asparagus and wheat. This supports the hypothesis of attachment of rhizobia to the root hairs and proves the process of root hair curling as non-host specific process (6). No evidence of infection thread or formation of nodules in B. campestris was observed. Role of a large amount of toxic gluconasturtiion present inside the plant tissues on thread can not be ruled out (34). Rhizobium requires the proper recognition of nutrients present in root exudates that allow rhizobia to colonize the rhizosphere of the non-legume and to curl the root hairs which is the prerequisite of symbiosis. Our data support that non-legumes too react with rhizosphere rhizobia but unlike Brassica napus, rice, etc. nodulelike structures on roots were not observed $(1,34)$.

Results of field experiments have proved that MP6 significantly (5\% level of LSD) induced seed germination, early vegetative and late reproductive growth (Table 5). Involvement of rhizobia in enhancement of plant growth and suppression of soil-borne fungi has earlier been reported $(22,16$, and 3$)$. Since MP6 has an antagonistic nature, its relative close adherence gives the protection during fungal infection that helps in establishing and resisting against preexisting deleterious microorganisms occupying the microbial niche in the rhizosphere. MP6 being a siderophore producing rhizosphere- competent bacterial strain, survives in soil, its PGPR traits help the enhanced plant growth and yield of $B$. campestris. It may be concluded that M. loti MP6 strain not only controlled $S$. sclerotiorum but also induced plant growth and yield of Indian mustard (B. campestris).

\section{ACKNOWLEDGEMENTS}

The financial supports from Technology Mission on Oil seeds, Pulses \& Maize and Council of Scientific \& Industrial Research, New Delhi are gratefully acknowledged.

\section{RESUMO}

\section{Mesorhizobium loti MP6 rizosférico competente induz encurvamento do pelo da raiz, inibe Sclerotinia sclerotiorum e estimula o crescimento de mostarda indiana (Brassica campestris)}

A cepa bacteriana Mesorhizobium loti MP6 isolada de nódulos de raiz de Mimosa pudica induziu o crescimento e o rendimento de Brassica campestris. A cepa MP6 secretou sideróforo do tipo hidroxamato em meio sólido Chrom-Azurol Siderophore (CAS). Em condições normais de crescimento, a cepa foi também capaz de produzir de ácido cianídrico $(\mathrm{HCN})$ e acido indolacético (AIA) e solubilizar fosfato. O encurvamento do pelo da raiz foi observado usando a simples técnica de lâmina e lamínula. Estudos in vitro mostraram um aumento significativo na população de $M$. loti MP6 na rizosfera devido aos exsudatos de B. campestris. Empregando-se técnica de co-cultura, a cepa mostrou um grande efeito antagônico contra o fungo Sclerotinia sclerotiorum, o patógeno da podridão branca de Brassica campestris. Após incubação prolongada, o crescimento de $S$. sclerotiorum foi inibido em $75 \%$. Uma eficiente colonização de sementes de mostarda foi confirmada pelo emprego da linhagem M. loti MP6strep+ que contém um marcador de resistência à estreptomicina. As sementes cobertas com M. loti MP6 apresentaram aumento da sua germinação,crescimento vegetativo rápido e melhor rendimento quando comparadas ao controle. Além disso, foi observado um drástico declínio na incidência da podridão branca decorrente da aplicação de $M$. loti MP6.

Palavras-chave: Biocontrole, rizobacterias promotoras de crescimento, colonização de sementes, podridão branca, Mesorhizobium loti, Brassica campestris

\section{REFERENCES}

1. Al-Mallah, M.K.; Davey, M.R.; Cocking, E.C. (1990). Enzyme treatment, PEG, biotin and nodule stimulation in white clover by Rhizobium trifolii. J. Plant. Physiol., 15, 225-258. 
2. Antoun, H.; Beaucham, C.J.; Goussard, D.N.; Chabot, R.; Lalande, R. (1998). Potential of Rhizobium and Bradyrhizobium species as plant growth-promoting rhizobacteria on non-legumes: effect on radishes (Raphanus sativus L.). Plant Soil, 204, 57-67.

3. Arora, N.K.; Kang, S.C.; Maheshwari, D.K. (2001). Isolation of siderophore- producing strain of Rhizobium meliloti and their biocontrol potential against Macrophomina phseolina that causes charcoal rot of groundnut. Curr. Sci., 81, 673-677.

4. Bhatia, S.; Bhatia, S.; Dubey, R.C.; Maheshwari, D.K. (2003). Antagonistic effect of fluorescent pseudomonas against Macrophomina phaseolina that causes charcoal rot of ground nut. Ind. J. Exp. Biol., 41, 1442-1446.

5. Biswas, J.C.; Ladha, J.K.; Dazzo, F.B. (2000). Rhizobial inoculation improves nutrient uptake and growth of lowland rice. Sci. Soc. Am. J., 64, 1344-1650.

6. Bodenoch-Jones, J.; Flander, D.J.; Rolfe, B.G. (1985). Association of Rhizobium strains with roots of Trifolium repens. Appl. Environ. Microbiol., 49, 1511-1520.

7. Breil, B.T.; Borneman, J.; Triplett, E.W. (1996). A newly discovered gene $t f u A$, involved in the production of the ribosomally synthesized peptide antibiotic trifolitoxin. J. Bacteriol., 178, 4150-4157.

8. Chabot, R.; Antoun, H.; Cescas, M.P. (1996). Growth promotion of maize and lettuce by phosphate-solubilizing Rhizobium leguminosasum biovar phaseoli. Plant Soil, 184, 311-321.

9. Chandra, S. (2004).Impact of rhizobia and chemical nutrients status on productivity of non-leguminous crop (Brassica campestris L. var. local). Uttaranchal, India. (Ph.D. Thesis, Gurukul Kangri University, Haridwar).

10. de Tempe, J. (1963). The blotter method for seed health testing. Proc. Int. Seed. Test. Assoc., 28, 1933.

11. Deshwal, V.K.; Pandey, P.; Kang, K.C.; Maheshwari, D.K. (2003). Rhizobia as biological control agent against soil borne plant pathogenic fungi. Ind. J. Exp. Biol., 41, 1160-1164.

12. Fahraeus, G. (1957). The infection of clover root hairs by nodule bacteria studied by a simple glass slide technique. J. Gen. Microbiol., 16, 374-381.

13. Gibson, F.; Magrath, D.E. (1969). The isolation and characterization of hydoxamic acid (aerobactin) formed by Aerobacter aerogenes. Biochem. Biophys. Acta., 192, 175-184.

14. Glick, B.R. (1995). The enhancement of plant growth by free living bacteria. Can. J. Microbiol., 47, 109-117.

15. Gu, Y.H.; Mazzola, M. (2001). Impact of carbon starvation on stress resistance, survival in soil habitats and biocontrol ability of Pseudomonas putida strain 2C8. Soil. Biol. Biochem., 33, 1155-1162.

16. Gupta, C.P.; Dubey, R.C.; Maheshwari, D.K. (2001). Antibiosismediated necrotrophic effect of Pseudomonas $\mathrm{GRC}_{2}$ against two fungal pathogens. Curr. Sci., 81. 90-94.

17. Gupta, C.P.; Dubey, R.C.; Maheshwari, D.K. (2002). Plant growth enhancement and suppression of Macrophomina phaseolina causing charcoal rot of peanut by fluorescent Pseudomonas. Biol. Fertil. Soils., 35, 399-405.

18. Hass, D.; Befago, G. (2005). Biological control of soil-borne pathogen by Fluorescent pseudomonads. Nat. Rev. Microbiol., 10, 1038, 1129141.
19. Hoflich, G.; Wiehe, W.; Buchnolz, C.H. (1995). Rhizosphere colonization of different crops with growth promoting Pseudomonas and Rhizobium bacteria. Microbiol. Res., 150, 139-147.

20. Holt, J.G.; Krieg, N.R.; Sneath, P.H.A.; Staley, J.T.; Williams, S.T. (1994). Bergey's manual of determinative bacteriology. Williams and Wilkins, London, p.151-157.

21. Kang, J.G.; Shin, S.Y.; Kim, M.J.; Bajpai, V.; Maheshwari, D.K. (2004). Isolation and antifungal activities of 2-hydroxymethylchroman 4one produced by Burkholderia sp. MSSP. J. antibiot., 5, 726-731.

22. Kloepper, J.W.; Schroth, M.N. (1981). Relationship of in vitro antibiosis of plant growth-promoting rhizobacteria to plant growth and the displacement of root microflora. Phytopathol., 71, 10201024.

23. Knowles, C.J. (1976). Microorganisms and Cyanide. Bacteriol. Rev., 40, 652-680.

24. Kuiper, I.; Kravchenko, L.V.; Bloemberg, G.V.; Lutenberg, B.J. (2002). Peudomonas putida strain PCL 1444, selected for efficient root colonization and nephthalene degradation effectively utilizes root exudates components. Mol. Plant. Microbe. Interact., 15, 734-741.

25. Lynch, J.M.; Whipps, J.M. (1990). Substrate flow in the rhizosphere. Plant Soil, 129, 1-10.

26. Miller, R.L.; Higgins, V.J. (1970). Association of cyanide with infection of birdfoot trefoil by Stemphylium loti. Phytopathol., 60, 104-110.

27. Neilands, J.B. (1981). Microbial iron compounds. Annul. Rev. Biochem., 50: 715-731.

28. Pikovaskya, R.I. (1948). Mobilization of phosphorus in soil in connection with the vital activity of some microbial species. Mikrobiol., 17, 362-370.

29. Planzinsky, J.; Innes, R.W.; Rolf, B.G. (1985). Expression of Rhizobium trifolii early nodulation genes on maize and rice plants. J. Bacteriol., $163,612-815$.

30. Schwyn, B.; Neilands, J.B. (1987). Universal chemical assay for the detection and determination of siderophores. Anal. Biochem., 160: 47-56.

31. Shimshick, E.J.; Hebert, R.R. (1979). Binding characteristics of $\mathrm{N}_{2}$ fixing bacteria to cereal roots. Appl. Environ. Microbiol., 38, 447453.

32. Skidmore, A.M.; Dickinson, C.H. (1976). Colony interaction and hyphal interference between Sartoria nodorum and phylloplane fungi. Trans. Brit. Mycol. Soc., 57-64.

33. Terounchi, N.; Syono, K. (1990). Rhizobium attachment and curling in asparagus, rice and oat plants. Plant. Cell. Physiol., 31, 119-127.

34. Trinick, M.J.; Habdobas, P.A. (1995). Formation of nodular structures on the non-legumes Brassica napus, B. campestris, B. Juncea and Arabidopsis thaliana with Bradyrhizobium and Rhizobium isolated from Parasponia spp. on legumes grown in tropical soils. Plant Soil, 172, 207-219.

35. Vincent, J.M. (1970). A Manual for the Practical Study of the Root Nodule Bacteria. IPB Handbook No. 15, Blackwell Scientific Publication, Oxford

36. Weller, D.M.; Cook, R.J. (1983). Suppression of take-all the wheat by seed treatment with fluorescent pseudomonads. Phytopathol., $23,23-54$. 